\title{
Capital Asset Pricing Model: Evidence from the Nigerian Stock Exchange
}

\author{
Afolabi, T. G. ${ }^{1}$; Njogo, B. O² (PhD); Areghan I. A³ Olugbenle A.H ${ }^{4}$; Olusesi H.O \\ ${ }^{1,2,4,5}$ Department of Economics, Accounting and Finance, College of management sciences, Bells University of Technology, \\ Ota, Ogun State, Nigeria. \\ ${ }^{3}$ Department of Economics \& Development Studies, Covenant University, Ota, Ogun State, Nigeria
}

\begin{abstract}
This paper critically examines the effect of capital asset pricing model (CAPM) for the Nigerian stock exchange using monthly stock values of 20 listed firms for the period of ten years (January 2006December 2015) covering the periods and the aftermath of the 2008/2009 global economic crisis. In order to enhance the precision of the beta estimates and reduce the statistical problems that arise from measurement errors in individual beta estimates, the securities were combined into portfolios. This study employed simple ordinary least square (OLS) regression technique and found no conclusive evidence for the application of capital asset pricing model (CAPM) in the Nigerian Stock Exchange.
\end{abstract}

Keywords- Capital Asset Pricing Model (CAPM), Nigeria Stock Exchange (NSE), Ordinary Least Squares (OLS) and Nigeria.

\section{INTRODUCTION}

The importance of capital market as an efficient channel of financial intermediation is crucial for financial sector development for any country globally. The Nigerian capital market has continued to play its traditional role of mobilizing medium to long-term funds for development purposes. The Securities and Exchange Commission (SEC) is the regulatory authority of the market and the operational institutions are the Nigerian Stock Exchange, the issuing houses and the stock broking firms. The stock exchange is one of the key institutions in the capital market which deals with efficient channel of funds from the surplus economic unit to deficit economy unit. The Nigeria Stock Exchange (NSE)which constitutes the hallmark of the Nigerian capital market plays an important role by enabling both the government and industries to raise long term capital and finance.

Capital asset pricing model (CAPM) as introduced by Sharpe et al (1964) postulates that expected return on an asset above the risk free rate is directly proportional to a non-diversifiable risk, i.e., a linear relationship exist between a residual risk and the value of an asset. The CAPM was developed as a model for investment appraisal, share valuation, and for pricing individual's securities or portfolio. CAPM assumes that individual's investment is characterized with two different forms of risk; the systematic and unsystematic risk. The systematic risks in the market that cannot be diversified are interest rate, recession and wars while unsystematic risks are specific risk to individuals stock (Oke, 2013). CAPM model drawn from the modern portfolio theory came into existence on how systematic risk can be measured. Given the recent capital market situation, Nigeria's stock values dropped as the Nigerian Stock Exchange has not been having the best of times as an aftermath of the global financial crisis due to an unprecedented surge in returns on investment which has resulted in a continuous downturn in market capitalization and thus many investors are not only interested for investment appraisal but eager to know what becomes of their investment. The Nigerian Stock Exchange started operations in 1961 with 19 securities listed for trading but presently there are 262 securities listed which is made up of 11 Government Stocks, 49 Industrial Loan (Debenture/Preference) Stocks and 194 Equity/Ordinary Shares of Companies, all with a total market capitalization of approximately $\$ 287.0$ billion, as at August 31, 1999. Currently, there are 139 listed equities while the all-share index and market capitalisation stood at 24,807 basis points and 1.973 trillion respectively as at December 3, 2010 (Nigerian Stock Exchange Equities Summary). Most of the listed companies have foreign/multinational affiliations and represent a cross-section of the economy, ranging from agriculture through manufacturing to services. The market has in place a tested network of Stockbrokerage Firms, Issuing Houses (Merchant Banks), practicing corporate law firms and over 50 quality firms of auditors and reporting accountants (most with international links). Prices of new issues are determined by issuing houses/stockbrokers; while on the secondary market prices are made by stockbrokers only.

\section{STATEMENT OF PROBLEM}

The stock exchange market in Nigeria has experienced significant development approximately 300 percentof stock market capitalization to real gross domestic product 
(RGDP) in the last three decadesbefore Nigeria lost \$1.9trillion in the stock market due to the latest financial melt-down in 2008 and from then till date, the market has been characterized with a downtrend season (AdedokunandOlakojo, 2012) which raises a lot of questions on appropriate model to be employed in evaluating the monthly values of the Nigeria stock exchange. Furthermore, the Nigeria stock exchange all share index was declared as the worst performing in the world having reviewed 91 shares across the globe (OlakojoandAjide, 2010). The functioning of the stock exchange market depends solely on an efficient capital market which influences the liquidity, risk diversification and mobilization of funds as posited by (Anyanwu, 1998 and Okereke-Onyuike 2000) remains a critical element in the sustainable development of the economy. Therefore financial reforms to aid the Nigeria stock exchange market was focused on further liberalization of banking business; ensuring competition and safety of the system and proactively positioning their interrelation with the capital market to boost financial intermediation. Some of these financial reforms includes: the formation of SecondTier Securities Market (SSM) established in 1985 geared to streamline the role of the Nigeria Stock Exchange market to cater for small and medium sized indigenous enterprise to gain access to the resources at the capital market for expansion and modernization.

Furthermore, The Central Securities Clearing System (CSCS) was institutionalized to provide an integrated central depository, clearing (electronic entry transfer of shares from seller to buyer) and payment for bought securities for all stock market transactions. It was incorporated as a subsidiary of the Nigeria Stock Exchange to obviate the inherent bottlenecks in the transaction process in the capital market and commenced operations in 1997. To this end, the CSCS is to implement a computerized Stock Exchange Management System (SEMS), which emphasizes immobilization of share certificates in the central depository and elimination of the bottlenecks between registrars and company executives in issuing new certificates to investors. In view of the Nigeria stock exchange performance in relation to policies discussed, this study examines the validity of Capital Asset Pricing Model (CAPM) in the Nigerian stock market using monthly stock values of 20 listed firms from January 2006 to December, 2015 covering the periods and the aftermath of the 2008/2009 global economic crisis.

\section{Research questions}

1. What is the effect of Capital Asset Pricing Model on the monthly stock values of 20 listed firms in Nigeria?
2. How does capital asset pricing model affect the Nigerian stock exchange?

\section{Research objectives}

The primary objectives of this seminar paper are to:

1. Critically discuss the effect ofCapital Asset Pricing Model on the monthly stock values of 20 listed firms in Nigeria.

2. Assess the correlation between capital pricing asset model and the Nigerian stock exchange

\section{Outline of study}

This paper is structured into five sections; section one is the general introduction that includes background to the study, research objectives and significance of study. Section two reviews literatures and empirical studies relative to capital asset pricing model, while section three discusses the methodology employed. Presentation of result and empirical findings are discussed in section four and conclusively, section five covers policy recommendation of the study.

\section{LITERATURE REVIEW}

\section{The logic of CAPM}

Capital Asset Pricing Model (CAPM) is one of the earliest theory that build on the earlier work of Harry Markowitz (1959) on diversification and modern portfolio theory. In Markowitz's model, an investor selects a portfolio at a previous period (time t-1) that produces a stochastic return at $\mathrm{t}$. The model assumes investors are risk averse and, when choosing among portfolios, they care only about the mean and variance of their one-period investment return (FamaandFrench, 2004). As a result, investors choose "mean-variance-efficient" portfolios, in the sense that the portfolios 1) minimize the variance of portfolio return, given expected return, and 2) maximize expected return, given variance. Thus, the Markowitz approach is often called a "mean-variance model'. The portfolio model provides an algebraic condition on asset weights in mean-variance-efficient portfolios. The CAPM turns this algebraic statement into a testable prediction about the relation between risk and expected return by identifying a portfolio that must be efficient if asset prices are to clear the market of all assets.

Sharpe (1964) and Lintner (1965) add two key assumptions to the Markowitz model to identify a portfolio that must be mean-variance-efficient. The first assumption is complete agreement. Given market clearing asset prices at $\mathrm{t}-1$, investors agree on the joint distribution of asset returns from $\mathrm{t}-1$ to 1 . If this distribution is the true one-that is, it is the distribution from which the returns we use to test the model are drawn. The second assumption is that there is borrowing and lending at a risk free rate, 
which is the same for all investors and does not depend on the amount borrowed or lent.

Also, the CAPM provides a relatively accurate prediction of the relationship that exists between a financial risk and the expected return (yield). The usefulness of the model lies in the fact that, on the one hand it offers the possibility of comparison of different variants of placement in the financial markets and, on the other hand, justifies the estimate on the scientific basis of the expected future value of profits generated by a financial instrument (AnghelandPaschia, 2013). The core of the CAPM model is represented by the beta coefficient which measures the sensitivity of the financial instrument in relation to the systematic risk.

\section{Empirical evidence}

Oke (2013) applied the Capital Asset Pricing Model (CAPM) to the Nigerian stock market using weekly stock returns from 110 companies listed on the Nigerian stock exchange (NSE) from January 2007 to February 2010. The study undermines the CAPM's predictions that higher risk (beta) is associated with a higher level of return and that the intercept should be equal to zero when estimating SML. The claim by the CAPM that the slope of the Security Market Line (SML) should equal the excess return on the market portfolio is also not supported by this study. This in effect, invalidates the prediction of the CAPM as far as Nigeria is concerned. Similarly, Adedokun and Olakojo (2012) investigated the empirical validity of CAPM in the Nigerian Stock Exchange (NSE) using monthly stock values of 16 firms from the 20 most capitalised firms in Nigeria between the period of January, 2000 and December, 2009. The empirical findings indicate that CAPM is inadequate to explain the role of asset risk for the determination of expected return on investment in Nigeria's equity market. They established contrary to the hypothesis of the CAPM that higher risk is associated with higher asset return and asset price.

Among the recent empirical studies are Olakojo and Ajide (2010) and Michailidis et al. (2006). They study the stock market in Nigeria and Greece respectively. The Greek security market was examined between January, 1998 and December, 2002 using weekly stock returns from 100 companies and the Nigerian stock Exchange was examined between the period of January, 2008 and December 2009 using monthly stock returns from 10 companies. Their findings are similar. They concluded that the CAPM's basic statement that higher risk (Beta) is associated with higher levels of returns and vice versa is not valid in the two countries.

Zhang and Wihborg (2004) employed monthly time series of share prices to analysis the pricing of equity in six
European emerging capital market; Cyprus, Czech Republic, Greece, Hungry, Russia and Turkey for the period of 1995 to 2002. They adopted both unconditional CAPM and made distinction between the domestic and the international CAPM.Their findings evidences from the sample of 753 firms across the six emerging markets indicates that there exists a significant conditional relationship between beta and returns when the domestic CAPM performs well only in two market, especially in more recent years. Also, a study of the nexus between the returns and higher-order systematic co-moments in the up and down markets by Galagedera and Silvapulle (2002) revealed that the expected excess rate of return is related to both beta and systematic co-skewness

From the above, it is clear that no consensus has been reached on the empirical validity of CAPM. Many researchers in their various efforts have included various forms of variables beyond the risk element (Beta) in CAPM to relate there effects to returns. Among such variables not mentioned earlier are the earnings yield (1977), leverage and ratio of a firm's book value of equity to is market value (Chan, et al., 1991) and conditional coskewness as a result of non-normality in stock prices (Javidand Ahmad, 2008).

\section{METHODOLOGY}

\section{Sample and data selection}

The study uses returns from 110 stocks quoted on the Nigerian Stock Exchange (NSE) and they are included inthe formation of the NSE all share Index for the period of January 2006 to December 2015. This index is designed to provide real-time measures of the NSE. All securities included in the indices are traded on the NSE on a continuous basis throughout the full NSE trading day. Each series consists of 120 observations of the monthly closing prices. The time period was chosen because it is characterized by intense return volatility with historically high and low returns for the NSE. The data were obtained from NSE database and all stocks returns are adjusted for dividends as stipulated by the CAPM.

In order to obtain better estimates of the value of the beta coefficient, the study employed monthly stock returns. The returns was calculated using a longer time period such as daily or weekly might result in changes of beta over the examinedperiod, thereby, introducing biases in beta estimates.

On the other hand, high frequency data such as daily observations covering a relatively short and stable time span can result in the use of very noisy data and thus yield inefficient estimates. Akintola-Bello (2004) also observes that there is no theoretically correct time interval for analysis. The sample size is based on the rationale of having sufficient information to efficiently estimate the 
market model and to ensure that the data is not going too far back in time. Thus, a tradeoff between enough observations to eliminate the impact of random rates of returns and an excessive length of time over which the subject company may have changed dramatically would be required.

The NSE All share index is used as a proxy for the market portfolio. This index is a market value weighted index and reflects general trends of the Nigerian stock market. Furthermore, the 1-month Nigerian Treasury Bill rate is used as the proxy for the risk-free asset. The yields were obtained from the Central Bank of Nigeria (CBN) website. The yield on the 1-month Treasury bill is specifically chosen as the benchmark that better reflects the short-term changes in the Nigerian financial markets.

\section{Estimation procedure}

This study follows the procedure of Oke (2013), and Mihailidis, Tsopoglou, Papanastasiou, andMariola (2006). The starting point is the estimation of a beta coefficient for each stock using weekly returns during the estimation period. However, in this study we estimate beta by regressing each stock's monthly return against the market index according to the following equation:

$\mathrm{R}_{\mathrm{it}}-\mathrm{R}_{\mathrm{ft}}=\alpha_{\mathrm{i}}+\beta_{\mathrm{i}}\left(\mathrm{R}_{\mathrm{mt}}-\mathrm{R}_{\mathrm{ft}}\right)+\varepsilon_{\mathrm{i}}$

Where;

$\mathrm{R}_{\mathrm{it}}=$ return on security " $\mathrm{I}$ " in " $\mathrm{t}$ " period ( $\left.\mathrm{i}=1 \ldots . .120\right)$

$\mathrm{R}_{\mathrm{ft}}=$ rate of return on risk-free security

$\mathrm{R}_{\mathrm{mt}}=$ the rate of return on market index

$\beta_{\mathrm{i}}=$ the estimate of beta for the security " $\mathrm{i}$ "

$\varepsilon_{\mathrm{i}}=$ the corresponding random disturbance term in the regression equation

Thereafter, the average portfolio excess returns of stocks (rpt) is computed and ordered according to their beta coefficient obtained by equation 1 ;

$\mathrm{r}_{\mathrm{p}}=\lambda_{0}+\lambda_{1} \beta_{\mathrm{i}}+\mu_{\mathrm{it}}$

$r_{p}=$ the average excess return on a portfolio " $p$ " (the difference between the return on the portfolio and the return

on a risk-free asset),

$\beta_{\mathrm{i}}=$ an estimate of beta of the portfolio $\mathrm{p}$,

$\lambda_{1}=$ the market price of risk, the risk premium for bearing one unit of beta risk,

$\lambda_{0}=$ the zero-beta rate, the expected return on an asset which has a beta of zero, and

$\mu_{\mathrm{IT}}=$ random disturbance term in the regression equation

\section{ANALYSIS AND DISCUSSION OF FINDINGS}

The beta estimates for the individual stocks derived from employing the observations on rate of returns for sequence of dates are presented in Table 1. The maximum estimate, minimum and ranges are 1.56, 0.266 and 1.294.
Subsequently, the study examines the CAPM assumption that higher risk (beta) is associated with higher level of return. This assumption is valid in the Nigeria stock exchange within the periods examined since the stocks with higher risks (portfolios A and B) are associated with the highest level of average returns while those with lower risk (portfolios $\mathrm{C}$ and $\mathrm{D}$ ) are associated with lower returns (as shown in Table 2).

The second assumption tested stated that the intercept $\left(\eta_{0}\right)$ equals to zero when estimating Security Market Line (SML) of equation 2. But, Table 3 indicates that the value of intercept is less than zero (-0.004) which is also less than the interest rate of risk free security of 0.089 . These results invalidate the zero beta assumption of the CAPM. While, the assumption that the slope of SML should equal to the excess return on the market portfolio was found to be invalid. Since the slope of estimated SML (1.1834) is less to the excess of return of market portfolio of 3.5675.Therefore, this study found that two out of the three assumptions of CAPM were inconsistent in the Nigeria Stock Exchange in the period examined (January 2006 to December 2015)and there is no statistically significant correlation between the average excess return on a portfolio $\left(r_{p}\right)$ and estimated beta of the portfolio $\left(\beta_{\mathrm{i}}\right)$ at 5 percent

The findings of this study is similar to those by Oke (2013),Adedokun and Olakojo (2012) and Olakojo and Ajide (2010) who provided evidence against the CAPM in NSE.

\section{CONCLUSION}

This study tested for the validity or otherwise of the assumptions of CAPM in Nigeria stock Exchange (NSE) using monthly stock returns from 20 companies often list among the most quoted companies in the country. The results conclusively invalidate the appli(2a)tion of CAPM in NSE. Thus, there is evidence of no correlation between the NSE and CAPM.

\section{REFERENCES}

[1] Adedokun, A. J. \&Olakojo, S. A. (2012). Test of capital asset pricing model: Evidence from Nigerian Stock Exchange. Journal of Economics Theory, 6(46), 121-127.

[2] Akintola-Bello, O. (2004). Stock market behaviour and performance. Lagos: Arbitrage Consulting Group.

[3] Anghel, M. G. \&Paschia, L. (2013). Using the CAPM model to estimate the profitability of a financial instrument portfolio. Annales Universitatis Apulensis Series Oeconomica, 15(2), 541-551 
[4] Chan, K. C. \&Nai-fu Chen (1991). Structural and return characteristics of small and large firms. Journal of Finance, 46, 1467-1484.

[5] Fama, E. F. \& French, K. R. (2004). The capital asset pricing model: Theory and evidence. Journal of Economic Perspectives, 18(3), 25-40.

[6] Galagedera, D. U. A. \&Silvapulle, P. (2002). Conditional relation between higher-order comoments and stock return: Evidence from Australian data. Proceedings of the Econometric Society Australasian Meeting, Queensland University of Technology, Brisbane, Australia.

[7] Javid, A. Y. \& Ahmad, E. (2008). Test of multimoment capital asset pricing model: Evidence from Karachi stock exchange. Pakistan Institute of Development Economics, Islamabad

[8] Lintner, J. (1965). The valuation of risk assets and selection of risky investments in stock portfolio and capital budgets. Review of Economics and Statistics, 47, 13-47.

[9] Markowitz, H. (1959). Portfolio selection: Efficient diversification of investments. New York, United States: Wiley \& Sons, Inc.

[10] Michailidis, G., Tsopoglou, S., Papanastasiou, D., \&Mariola, E. (2006). Testing the capital asset pricing model (CAPM): The case of the emerging Greek securities market. International Research Journal of Finance and Economics, 4, 79 - 91.

[11] Olakojo , S. A. \&Ajide, K. B. (2010). Testing the capital asset pricing model (CAPM): The case of the Nigerian securities market. International Business Management, 4, 239- 242.
[12]Oke, B. O. (2013). Capital Asset Pricing Model (CAPM): Evidence from Nigeria. Research Journal of Finance and Accounting, 4(9), 17-26.

[13] Sharpe, W. F. (1964). Capital asset prices: A Theory of market equilibrium under conditions of risk. The Journal of Finance, 19(3), 425-442.

[14]Zhang, J. \&Wihborg, C. (2004). Unconditional and conditional CAPM: Evidence from European emerging markets, 256-266.

\section{APPENDIX}

Table.1: Individual Stock Beta Coefficient Estimates

\begin{tabular}{|l|r|r|}
\hline Stock & Estimated Beta & Rank \\
\hline NBC & 1.56 & 1 \\
\hline UBA & 1.51 & 2 \\
\hline FIDELITY & 1.46 & 3 \\
\hline GTB & 1.28 & 4 \\
\hline FLOURMILL & 1.21 & 5 \\
\hline FCMB & 1.18 & 6 \\
\hline UACN & 0.84 & 7 \\
\hline FBN & 0.77 & 8 \\
\hline CCNN & 0.692 & 9 \\
\hline CHELLARAM & 0.6 & 10 \\
\hline CILEASING & 0.54 & 11 \\
\hline CADBURY & 0.32 & 12 \\
\hline NBC & 0.306 & 13 \\
\hline PZ & 0.302 & 14 \\
\hline MOBIL & 0.3 & 15 \\
\hline OANDO & 0.298 & 16 \\
\hline TOTAL & 0.29 & 17 \\
\hline GUINNESS & 0.286 & 18 \\
\hline CONOIL & 0.271 & 19 \\
\hline UNILEVER & 0.266 & 20 \\
\hline
\end{tabular}

Source: Author's Compilation from NSE Database

Table.2: Portfolio classification

\begin{tabular}{|l|r|r|r|r|r|}
\hline \multicolumn{7}{|c|}{ PORTIFOLIO A } \\
\hline Firms & Estimated Beta & Rank & Average excess returns & \multicolumn{1}{c|}{ Rank } \\
\hline NBC & 1.56 & 1 & 0.00469734 & 7 \\
\hline UBA & 1.51 & 2 & 0.001441146 & 6 \\
\hline FIDELITY & 1.46 & 3 & 0.00661392 & 5 \\
\hline GTB & 1.28 & 4 & 0.018855228 & 13 \\
\hline FLOURMILL & 1.21 & 5 & 0.011570356 & 2 \\
\hline & & & & 0.008635598 & \\
\hline & Pstimated Beta & Rank & Average excess returns & Rank \\
\hline Firms & \multicolumn{2}{|c|}{ PORTIFOLIO B } & 0.007710406 & 8 \\
\hline FCMB & 1.18 & 6 & 0.005886002 & 3 \\
\hline UACN & 0.84 & 7 & 0.000763567 & 11 \\
\hline FBN & 0.77 & 8 & -0.001849398 & 15 \\
\hline CCNN & 0.692 & 9 & & \\
\hline
\end{tabular}




\begin{tabular}{|c|c|c|c|c|}
\hline CHELLARAM & 0.6 & 10 & -0.000633573 & 1 \\
\hline & & & 0.002375401 & \\
\hline \multicolumn{5}{|c|}{ PORTIFOLIO C } \\
\hline Firms & Estimated Beta & Rank & Average excess returns & Rank \\
\hline CILEASING & 0.54 & 11 & 0.001106273 & 4 \\
\hline CADBURY & 0.32 & 12 & 0.001106273 & 18 \\
\hline NBC & 0.306 & 13 & 0.000473529 & 19 \\
\hline $\mathrm{PZ}$ & 0.302 & 14 & -0.000883578 & 14 \\
\hline \multirow[t]{2}{*}{ MOBIL } & 0.3 & 15 & -0.000740573 & 10 \\
\hline & & & 0.000212385 & \\
\hline \multicolumn{5}{|c|}{ PORTIFOLIO D } \\
\hline Firms & Estimated Beta & Rank & Average excess returns & Rank \\
\hline OANDO & 0.298 & 16 & -0.000209218 & 17 \\
\hline TOTAL & 0.29 & 17 & 0.001237773 & 16 \\
\hline GUINESS & 0.286 & 18 & -0.002807257 & 9 \\
\hline CONOIL & 0.271 & 19 & 0.002025761 & 20 \\
\hline \multirow[t]{2}{*}{ UNILEVER } & 0.266 & 20 & 0.001048808 & 12 \\
\hline & & & 0.000259174 & \\
\hline
\end{tabular}

Table.3: Summary of Security Market Line (SML) results

\begin{tabular}{llrl}
\hline Dependent Variable: D(IGR) & Coefficient & t-value & P-value \\
\hline Alpha & -0.004 & -2.771 & 0.010 \\
Beta & 1.1835 & 9.496 & 0.000 \\
\hline Adj R square $=0.719$ & & & \\
Prob (F-statistic) $=0.0017$ & & & \\
\hline
\end{tabular}

Source: Author's computation (2017) using E-view (8.0)

Table.4: Correlation Matrix

\begin{tabular}{|c|c|c|}
\hline & Returns on Portfolio (Rp) & Estimated Beta on Portfolio $\left(\beta_{i}\right)$ \\
\hline (Rp) & 0.001531 & 0.200731 \\
\hline$\left(\boldsymbol{\beta}_{\mathbf{i}}\right)$ & -0.005822 & 0.6679 \\
\hline
\end{tabular}

